\title{
Childhood, Play and School: A Literature Review in Australia
}

Infancia, juego y escolaridad: una revisión bibiliográfica en Australia

Review paper | Artículo de revisión

Received on: August $26^{\text {th }}, 2019$

Accepted on: November 12 12019

Available online from: November 2020

doi: 10.11144/Javeriana.m13.cpsl

Catherine Holmes catherine.holmes@anu.edu.au

Australian National University, Australia D ORCID: https://orcid.org/0000-0002-0248-3654

Para citar este artículo | To cite this article Holmes, C. (2020). Childhood, play and school: A literature review in Australia. magis, Revista Internacional de Investigación en Educación, 13, 1-25. doi: 10.11144/Javeriana.m13.cpsl 


\begin{abstract}
Around age three, First Nations children in remote communities in Australia undertake a major transition from the home to formal schooling. This very important period of child development is typically monitored by non-First Nations educators. Yet these educators typically know little about First Nations child development of children aged birth to seven. The purpose of this review is to demonstrate the importance of describing the process of acquiring social and cultural practices that enable a child to become a dynamic, knowledgeable participant in a First Nations context from a strengths perspective.
\end{abstract}

\title{
Keywords
}

Australia; childhood; literature; play; schools

\section{Resumen}

Alrededor de los tres años, los niños de las naciones originarias en las áreas remotas de Australia inician una transición importante de la formación en casa a la formación escolar. Este periodo, que es muy importante en el desarrollo de los niños, se monitorea por educadores que no provienen de estas comunidades y que saben poco sobre el desarrollo de los niños de entre los 0 a 7 años de edad en las naciones originarias. Esta revisión tiene como propósito demostrar la importancia de describir el proceso de adquisición de prácticas sociales y culturales que le permiten al niño ser un participante dinámico y entendido en el contexto de las comunidades originarias desde una perspectiva de fortalezas.

\section{Palabras clave}

Australia; infancia; literatura; juego; escuela 
Article description | Descripción del artículo

The following review article, derived from the research project Tjitji kutjuparriku (in Ngaanyatjarra)-Tjitji Tjiyinytjiku

(in Pintupi)-The changing nature of childhood (A study

of child development from an Indigenous perspective in

Australia: An interpretive approach to socialisation, reviews the current literature relating to childhood, play and schooling in Australian First Nations contexts. The review focuses on

children aged birth to seven, in the early years.

\section{Introduction}

The child is universal and childhood is experienced by all human beings however, geographically, the study of childhood and child development has principally been concerned with Western countries which the populations "comprises of ten percent of all children in the world" (LeVine $\&$ New, 2008). Most of the children in the world are from non-Western countries however, the foundation of education and more specifically, early childhood policy and practice across the globe stems from Western fields. Furthermore, policies derive from Western theoretical frameworks, epistemologically, ontologically and axiologically (Martin, 2008; Martin \& Mirraboopa, 2003; Nakata, Nakata, Keech \& Bolt, 2012). Childhood field studies by anthropologists began in the early-1920s and the accounts presented evidence that children all over the world were being raised with differing cultural practices and cultural variations (Gutiérrez \& Rogoff, 2003).

To date, majority of human development research has been carried out in "middle-class communities in Europe and North America" (Rogoff, 2003, p. 4) and from this research generalisations have been broadened to universal terms. However, the early cultural research from Malinowski (1927) and Piaget \& Cook (1952) in which both researchers assisted in the foundation for all human beings to not be placed as 'the same' however, on the contrary. Cultural research in human developments seeks to "move beyond overgeneralisations that assume that human development everywhere functions in the same ways as in researchers' own communities, and to be able to account for both similarities and differences across communities" (Rogoff, 2003, p. 7).

Through the zone of proximal development, Vygotsky (1967) argued that it is through the child's skills and tools that they learn in their culture, that he or she can participate effectively in activities and learning and many scholars have supported these claims (Heath, 1983, 1989; Miller, 1982; Ochs, 1988; Rogoff \& Chavajay, 1995; Rogoff, Mistry, Göncü 
\& Mosier, 1993). These cultural tools and skills are transgenerational and change over time through adaptation. However, Rogoff argues further that human development is the combination of individual participation and sociocultural change from others $(1990,1998)$. As children participate in cultural activities with others, they develop their tools and skills. From a theoretical perspective, recent works have explored the universal roots of childhood through ethnography and human development. This is due to participants being key components of cultural transmission within a community (Rogoff, 2003).

\begin{abstract}
Aims view process:

- Evidence and literature relating to childhood

- Evidence and literature relating to play

- Evidence and literature relating to schooling
\end{abstract}

The aim of this literature review has been to present an analysis of information and evidence from literature and resources associated with childhood, play and schooling in remote contexts across Australia in the early years (birth to seven). There were three central intentions to the re-

These three central intentions form the basis of the main sections of the review. Where necessary, there has been an indication that there has been literature absent and further research could be carried out.

\title{
Evidence and Literature Relating to Childhood
}

During the late ninetieth and early twentieth century, the most common topic in childhood literature in First Nations contexts in Australia surrounded boys' initiation however, conception, totemism, the family and life cycle were briefly discussed. However, these topics were only discussed from a classificatory perspective with little theoretical interpretation. Two authors of the time period, Brown (1913) and Malinowski (1913) should be identified due to their contribution to the social evolutionary paradigm. Specifically, Malinowski wrote of a social morphology of the Aboriginal family and Brown with the trailblazing Western Australian conceptualisation of the section and subsection systems.

In the late-1970s, literature began to be presented from a First Nations perspective by illustration and by anecdotal record. In 1977, the text The Aboriginal Children's History of Australia was published and aimed 
to outline the history of Australia in illustrations by Aboriginal children. In Coombs, Brandl \& Snowdon (1983) text, A Certain Heritage: Programs for and by Aboriginal Families in Australia and Isaacs (1992) book, Australian Dreaming, both began to present anecdotal accounts of childhood or the early years by First Nations adults however, little detail was provided.

\section{Pregnancy and Birth: Antenatal, Intrapartum and Postnatal Care}

In the early 1990s, Isaacs (1992) documented anecdotal stories across 'Aboriginal Australia' and in the process, he collected brief stories that related to pregnancy and childhood birth from Yirrkala in northern Australia. In 1996 the text, Keeping Company, outlined "birthing protocols" (Franks \& Curr, 1996, pp. 57, 83) and the importance of place and the process of naming by Arrernte Peoples in Central Australia. Playground (2017), compiled by Nadia Wheatley with the Indigenous consultant, Dr. Jackie Huggins, the First Nations Consultant, collected a range of stories from various sources around Australia. From a health focus, Hancock (2006) presented a literature review of Aboriginal women's perinatal needs, experiences and maternity services. This piece of literature outlined information and evidence related to the experiences of Aboriginal women and; the evaluation and quality assessment of antenatal, intrapartum and postnatal care. Hancock also summarised each state and territory's services, highlighted the remote location issues and; acknowledged sensitivity, cross cultural communication, shame and tjukurrpa as areas of difference with Aboriginal women. Missing from the literature is a contemporary view of pregnancy, birth and antenatal care from the current day practices in remote locations in regard to travel, 'waiting' time or 'sit down' time. There is also a lack of literature of First Nations women's perspectives during antenatal, intrapartum and postnatal care. In particular, it should be noted that there is little acknowledgement of trauma experienced by women who are required to birth away from their home country, in hospitals with limited support networks.

\section{Birthplace and Conception}

The concept of conception and birthplace has been explored for connection to country, land ownership and art-based reasons however, greater focus could be placed on the importance of birth and conception to inform childhood developmental milestones and identity within remote settings. Brooks \& Jorgensen (2015) discussed the relevance of birthplace and conception place in relations to art in the Ngaanyatjarra region. From an 
anthropological perspective, birthplace and conception has also been briefly documented in the Western Desert region by Merlan (1997) in relation to Native Title and land ownership in the CAEPR Monograph 12: Fighting over Country: Anthropological Perspectives (edited by Smith \& Finlayson).

\section{Child-Focused Research}

Towards the end of the 1920s and into the 1930s, two writers emerged in relation to childhood. These were: ethnographer Roheim (1974, 1988) and anthropologist, Thomson (1936, 1946, 1975, 1983), they documented observations and annotations of infants, childhood and the socialisation techniques of caregivers in Arnhem Land and Central Australia. Roheim was the first author to document play illustrations in Australia that provide understanding of the inner life of a child and their social practices. During 1929, Rohiem (1974) conducted eight months of fieldwork in Central Australia. Throughout this period, Rohiem used "protective play techniques" (Eickelkamp, 2010, p. 149) to delve into the inner life of a child's social practices, providing a child's point of view however, both authors presented childhood and play from a Western construct and as 'exotic' participants. Similarly, in 1968, Phyl and Noel Wallace published the text Children in the Desert, which presented a range of short case studies with images of Pitjantjatjara children. The authors highlighted the children's ability to be resourceful with games and play materials, children interacted with the siblings rather than dolls, they engaged in hunting and gathering for rabbits and maku (witchetty grubs), searching for water and played "story time" (Wallace \& Wallace, 1968, p. 24). In relation to the school learning environment, Wallace \& Wallace (1968) stated "The desert children enter a strange new world when they step into a school room, and at first its restrictions must be agonising to them. There is so little in our school activities that relates to their traditional background" (p. 36). Thomson's (1983) text, Children of the Wilderness described the everyday activities of children in a variety of regions across Australia and one of the regions is the 'Desert Dwellers'. He highlights that children are cared for by their siblings and "their play is based on imitation of the life activities of adults" (Thomson, 1983, p. 74). From the 1940s to 1980 s, ethnographic fieldwork firmly broadened the literature into "kinship, comparative social organisation, male ritual life and mythology" (Eickelkamp, 2010, p. 150). Since the 1970s, anthropologists have studied autonomy from a cultural, personal and political perspective within Aboriginal cultures. A key contribution during this period was from Myers (1991) relating to concepts of growing up. Through his research with Pintupi People, Myers made 'autonomy and relatedness' 
familiar terminology within Aboriginal studies. Three key ethnographers relating to psychological studies during this period were: Hamilton (1981) for the comments on attachment in North-Central Arnhem Land, Morton's (1989) psychoanalytic explanation of the emblematic representations of the mother-child in some cultural institutions and Robinson's (1990) continuous research of changing family dynamics in the Australian First Nations context. Missing from the literature is the perspectives of First Nations People.

\section{Child Rearing Literature}

The beginning of child rearing research in First Nations Australia began with Hamilton's (1981) study, Aboriginal Child-rearing in North-Central Arnhem Land, which highlighted interpretations of attachment. The main aim of Hamilton's (1981) study was to acquire information surrounding child rearing techniques of the Anbarra People however, methodologically the study did not include an Anbarra research collaborator(s). Similarly, Martu tjitji pakani (Jewell, 2008), a doctoral thesis on Martu child rearing practices and their implications on the child welfare system methodologically did not privilege the voices of Martu Peoples.

In the early-2000s, a range of child rearing literature came from Central Australia Waltja Tjutangku Palyapayi Aboriginal Association (2001) and Priest, King, Brown, Nangala \& Nangala (2007). Both pieces of literature provided an overview of specific programs undertaken in Central Australia outlining the differences of Western and Walpiri child rearing practices. Sadly, programs both discontinued due to the change in policy which moved towards a more paternalistic narrative. More recently, child rearing research has included First Nations authorship. Kruske, Belton, Wardaguga \& Narjic (2012) conducted research with fifteen families in the Northern Territory with multilingual First Nations researchers to plot the families view of their child's growth and development for the first year of life. The Byers, Kulitja, Lowell \& Kruske (2012) paper entitled "'Hear our stories': Child-rearing practices of a remote Australian Aboriginal community", presented a longitudinal case study conducted by Yolnu researchers. The authors suggested that Yolnu Peoples feel that they are forced to be white in the space of early childhood education. Methodologically, First Nations Peoples have been included in the research process and this practice could be expanded in other remote First Nations contexts.

There has also been a range of studies into strength-based approaches in Australia. In particular, Geia, Hayes \& Usher (2011) used a strength-based approach to provide better outcomes for Aboriginal children and families by exploring child rearing practices. Lohoar, Butera \& Kennedy (2014) 
reviewed strengths-based child rearing practices in three locations: Victoria, Queensland and Northern Territory with sixteen participants. Fiona Ryan (2011) used "Kanyininpa", meaning holding, looking after, nurturing (also documented by Myers, 1991, specifically in Pintupi country) to explore child rearing practices and attachment theory. Myers (1991) discussed the nurturing circumstance from childhood into adulthood.

\section{Social Relations Literature}

The first major input into the literature surrounding First Nations children in Central Australia region was Malinowski's doctoral dissertation into the sociology of Aboriginal family life. Although the work discussed concrete occurrences of customs, he recognised the durable emotional connection between children and parents as the primary caregivers. From a parental view, Malinowski described postnatal childhood experiences relating to life such as breastfeeding, caregiver roles and infant care. In 1925, the first university department of anthropology opened in Australia and during the course, one piece of literature was of relation to childhood, Kaberry ([1939] 2003). Kaberry was one of the first female fieldworkers in the field and she established annotations relating to the relationships between mothers and children.

In relation to the definition of parent, caregiver and family, it is important to note: the term 'family' within a First Nations Australian kinship system has a different definition to a non-First Nations Australian (Morphy, 2006). The definition of family for First Nations Peoples in Australia has been documented by a range of authors. Gray, Trompf \& Houston (1991) discussed the term 'family' in relation to contemporary patterns of demography and the implications for children and welfare.

Robinson $(1990,1992)$ underlined the research of changing family dynamics. Morphy (2006) presented an in-depth discussion of the term 'family' for peoples living in remote Australia. However, the literature does not provide an ethnographic perspective in relation to the care of a child from extended family and the wider community. A small range of sources have briefly stated the role of the extended family such as kinship network and grandparents however, greater focus could be placed on the role of non-biological fathers, mothers and siblings care. Examples include: Keeping Company (Franks \& Curr, 1996) noted the shared caregiving role of people related to kinship network for Arrernte Peoples in Central Australia. Mothers are responsible for feeding and nurturing however, other kin relatives are collectively responsible for supporting the child when sick, general guidance, teaching and ceremonial life as learning and caregiving is generally 
more holistic and the kinship network is very important to this child rearing process. The role of grandparents was also specifically noted as they teach children how to walk, talk, relate to others, kin and skin groups and cultural practices. Morton (1989) emphasised psychoanalytic explanations of mother-child links, Ryan (2011) discussed the role of men in children's lives, as did Dodd \& Jackiewicz (2015) regarding the relation of fathers and mothers in sleeping arrangements specifically, co-sleeping.

Peer play interactions have been well documented across the world however, there is a limited body of research of First Nations children and young people in Australia. O'Shannessy (2011) presented a snap shot of a Warlpiri community were children used "talk and play to reproduce and explore cultural practices" to "explore peer alliances that assist them with dealing with their wider social group" (p. 153). Children speak Light Walpiri and Baby Talk with one another. The focus area of this research is small and could be expanded to a range of First Nations contexts to better document social relationships and relationship to play in the early years.

\section{Two Worlds' Literature}

From the mid-1970s, literature began to describe First Nations Peoples living and navigating 'two worlds' or 'both worlds'. McCoy (2009) suggests there are two cultures in Australia: the "Western and white world-view" (Western) and the "Indigenous and 'traditionalist' world" however at times, they may "unite, blend, amalgamate, compromise and negotiate" (p. 21). The two earliest pieces of literature relating to 'two worlds' are: 1) The People in Between by Winified Hilliard (1968), a non-fiction book about Pitjantjatjara people of Ernabella and 2) Boy Between Two Worlds, a fiction text about Tjakamarra, a young desert boy, by Mary Durack in 1977. However, today in contemporary society, the rhetoric lives on. In 2006, Channel 9 (an Australian television channel) opened the Wadeye Program (a show about a community in the Northern Territory) with "the young people of Wadeye being caught between two worlds" (McCoy, 2009). The 'two worlds' rhetoric continues to live on in today's narrative of people living in remote locations in Australia however, greater focus could be on the everyday, contemporary life as a child in these regions from a holistic perspective. Can a child's life be separated or split in two, separated like oil and water? Or is the modern world for First Nations children the combination of these 'two worlds', woven and intertwined. The interwoven nature of the contemporary First Nations child thus should be explored as iPads and Smartphones are being used whilst hunting, Facebook posting during ceremonial practices or Baby Shark lyrics as a child's first words. 


\section{Evidence and Literature Relating to Play}

In Australia, play within a remote First Nations context has been studied in a range of geographical locations (Eickelkamp, 2005, 2011; Haagen, 1994; Jacobs, 1988; Kral \& Ellis, 2008; O'Shannessy, 2005; Shaw, 2002). These studies highlight the presence of play within First Nations contexts, however little information has been presented that focuses on the challenges in transitioning children aged zero to seven from the home environment to formalised school settings. Additionally, there is limited literature on the effect of environmental variables in the natural setting (see for example, Eickelkamp, 2011; Simpson \& Wigglesworth, 2008; Disbray, 2008; Musharbash, 2013; Tonkinson, 2013).

There has been a limited range of literature related to children's games. Mountford (1973) outlined two observations from the Pitjantjarara region, one of a boys ceremony aged seven to thirteen and the other, a girls' leaf game, muni muni. Woenne (1973) gave a brief detail of children's games in the Docker River region, discussing babyhood, natural materials, "seldom manufactured games", times of day for certain activities and gender differences. However, all these areas of research could be explored in greater depth from an early years, zero to seven age range.

Story games using eucalyptus leaves that represent family groupings has been documented in Yuendemu (Haagen, 1994) and the use of a 'story wire' for sand stories has been discussed by Ellis, Green, Kral \& Reed (2019), Ute Eickelkamp (2008) in the Ngaanyatjarra and Pitjantjatjara Lands in Central Australia. The story wire can be used in the Ngaanyatjarra Lands to play mama mama ngunytju ngunytju 'father father mother mother' (Ellis et al., 2019), a guessing game related to social networks. The study highlighted the evolving nature of language socialisation and spatial awareness in the region and the use of multimodal evaluation to understand unforeseen teaching and learning practices in local knowledge systems (Ellis et al., 2019). Across First Nations contexts in Australia, there is a current lacuna of research in relating to cultural variations such as the presence or absence of physical objects such as toys, books, digital devices, television, child-oriented educational aids, play objects, common characteristics of playmates and parental attitudes (Heath \& Street, 2008).

\section{Objects}

Haagen (1994) wrote a key piece of literature entitled Bush Toys, Aboriginal Children at Play that described children's toys not being a key 
competent of childhood ${ }^{1}$. On Mornington Island, dolls have been made with sticks and clay and in later years, collectors have begun to collect cars and swords from Yuendumu (Haagen, 1994). She noted that the toys during infancy were not used to the same extent as Western families. In 1899, the first toy artefacts were collected. These consisted of three rattles, collected from Mapoon, Batavia River and Cape York. Plus, an infant toy with three rings made from cabbage palm fibre. This literature could be expanded to include modern bush toys in remote communities generally and in specific regions due to different regional influences.

Within manufactured objects, 'bush toys' should be noted to understand the history and nature of adaptation with manufactured objects into toys or artefacts within rural and remote regions of Australia. In 1999, Liesl Rockchild's book, Bush Toys: A Living History, documented the creation of bush toys made from recycled materials from stockyards and rodeos. Adult artists from Eastern Arrernte communities, namely, Ltyentye Apurte, Titjikala and Engawala, created the artefacts and a text documented children using them. Artefacts included, kangaroos, motor bikes, horses, stockmen, cowboys, cattle trucks, windmills, helicopters and motor cars. Due to the limited access to manufactured objects from shops, children and adults were creating their own objects to 'play with'. Rockchild (1999) created an exhibition of these bush toys from the Eastern Arrernte region. However, no collection or database has been created for the wider First Nations context.

In the 'old times' (pre-contact time) in the Eastern Arrernte region, Kathleen Wallace traditional landowner of Ltyentye Apurte, born in 1948 recalls playing with "little spears and boomerangs. Then the station owners came in, bringing horses and cattle. At that time, the kids would watch the stationer, the kids would get other ideas for making things" (Rockchild, 1999, p. 10).

In the 'early times' of the region, children played with clay from the creek in the wet times of the year, gathering wet mud and creating horses, fences and saddles (Rockchild, 1999). Douglas Wallace was born in 1940, a traditional landowner of Ltyentye Apurte, he remembers the time when "whitefella toys weren't around, we made our own toys to play with. We'd leave them out and when the rain came at night it would destroy them. Then we'd make some more" (Rockchild, 1999, p. 10).

In the 1940s and 1950s, Rockchild (1999) highlighted children were playing with leftover materials from the station owners and natural

1 In fact, within Australia museums there are only five examples of toys such as: digging sticks and firesticks. 
materials constructing wooden cars "by attaching wooden wheels to a piece of wood; old metal pipes were used to make axels and were doubled over at the ends to hold the wheels in place" (p. 15). Other objects included, sides made from bullock hides, flying foxes made with a rope and small pipe; tin buggies or little jeeps, made with tobacco tins and wire (Rockchild, 1999). The toys were described as "full of potential and made with loving care, and should be viewed as such, as well as being indicators of a rich cultural life and history" (p. 19). Rockchild (1999) specifically highlighted that bush toys were generally produced by boys and young men. Girls and young women tended to make "playthings of a more domestic nature. Such as small houses, cooking implements and rag dolls" (p. 15). Considering this information, gender specific toy production and usage could be explored in greater detail to inform contemporary gender specific practices in remote areas. Kimber presented a brief history of toys in Central Australia (Rockchild, 1999). In this history, Kimber highlighted in the importance of fire as a toy to not only make digging sticks and wooden vessels but for celebration, ceremony, food preparation but also for play with children. The concept of fire could be expanded and understood from everyday use of a modern child in a remote First Nations context. It should also be noted that there is a lack of literature relating to the use of home objects and utensils as play objects. This missing piece of literature could help to better understand the cross-usage of everyday objects with children.

According to Kimber, the most common bush toy modified from a manufactured object was the empty or partially sand filled treacle tin and the object was used to play the "motor car" game or "road-grader" game (Rockchild, 1999, p. 34). According to Kimber (Rockchild, 1999) children were often playing with crow bars and other hunting objects when out bush or in the community. Other objects such as matchboxes and cards came to Central Australia by the arrival of trains in the 1930s. During this time, toy rifles, aeroplanes and telephones (two tins and a string) were also very popular with boys across Australia due to the war (Rockchild, 1999). During the 1950s and 1960s, there was an increase of Australia-wide vehicle ownership however, this did not reach remote regions until the 1970s. When vehicles did reach remote regions, they were used for food and other essential supplies so the "proliferation of plastic and other toys" was available only in Alice Springs and not to remote communities.

In 2014, researchers sought to understand food security issues in Western Australian remote communities (Pollard, Nyaradi, Lester \& Sauer, 2014). The research was conducted by phone interview with remote store managers. The key findings of the literature related to the cost of freight and irregular deliveries of food supplies. It should be noted that the study 
did not mention toys, objects or items related to technology such as phones, tablets and gaming consoles. This is a lacuna of research across Australia into how remote stores source, price goods as well as the ethical and environmental factors of supplying toys, objects or technology to children and families in remote areas.

\section{Technology}

Specifically, in First Nations communities in Australia, Emery \& Habel (2017) produced an article entitled "Video games and Indigenous education: Let's bridge the 'epistemology gap'". The article presented the notion that there are epistemological differences in 'Indigenous and non-Indigenous' worlds and game-based learning may address this gap. In remote regions of Australia, access to technology and devices is a key theme in contemporary literature and public policy. The first sign of digital technology in remote Australia were from the television. Television was first launched in Australia in 1956 however, it wasn't until 1971 that it reached Alice Springs. Kimber (Rockchild, 1999) states that this was due to the influence of the "Space Base", the American children living with their parents who worked at Pine Gap, the US base just outside Alice Springs. However, television didn't reach remote areas until the 1980s, with the inception of Impartja Television Pty Ltd. Currently, there is limited literature reviewing the impact of technology and specifically digital technology on childhood particularly in the early years. This is due to the recent inception of portable computer devices such as the tablets and smart phones, limited longitudinal research has been carried to see the impacts of young children.

\section{Language Acquisition}

Walker (Jacobs, 1988) was one of the first researchers to explore "pragmatic purpose of language in Aboriginal children" (p. 3). In Australia, there are a range of diverse ways First Nations children are learning language and there has been limited research into the impact of child rearing and language learning (Simpson \& Wigglesworth, 2008). Research carried out by Haviland (1998) described language acquisition in relation to cardinal directions in Guuyn Yimithirr language in north Queensland. On two occasions, the author commented on children using cardinal directions however, there is no information about the learning process of children and cardinal direction. Similar research was carried out in Arrernte country in Central Australia by Wilkins (2006) and like the previous article, a small mention was made in relation to the learning process as a child. However, in majority 
of First Nations contexts, this is a lacuna of research in the learning processes of cardinal direction in childhood.

Current linguistic research surrounding language acquisition is from Simpson \& Wigglesworth (2008), Langlois (2004), O'Shannessy (2005), Kral (2007), and Kral \& Ellis (2008), however, these studies do not include children aged zero to three years.

The main concept discussed in early years research in remote areas is realted to 'baby talk'. Kral \& Ellis (2008) described the use of baby talk in the Ngaanyatjarra region as it begins at the start of a baby's life through the "tactile interaction: cuddling, pinching of cheeks and kissing, in conjunction with the undulating prosodic contours of 'baby talk'" (p. 156). The authors found that Ngaanyatjarra babies and adults were participating in linguistic social and cultural processes. Baby talk has also been documented in Yuendemu (Bavin, 1993; Laughren, 1978).

Like many other First Nations cultures across the globe, oral narratives are the focal practice to learning (Kral \& Ellis, 2008; Rogoff, 2003). Storytelling and 'language play' have been documented in language learning in the Ngaanyatjarra and Pintupi region (Ellis et al., 2019; Kral \& Ellis, 2008). Storytelling is a teaching method that is passed down through generations to "share and record culture and history" (Emery \& Habel, 2017, p. 17). Disbray's (2008) research in Tennant Creek explored the collaborative and co-constructed means in which adults relate with children during storytelling. However, the research did not specifically describe early years learning. The author noted adults using a mixture of first language and English language, Warumungu and Wumpurrarni English. Storytelling begins in the home environment by the family and Disbray identified two interactional styles in relation to adult storytelling: "elaborate narration" and "collaborative narrations" (p. 73). These styles are labelled as a model for 'good storytelling'.

Sand storytelling is a cultural practice that provides a platform for creativity and expression. Eickelkamp (2008) and Ellis et al. (2019) have all recently conducted research around the use of sand stories and the links to socio-spatial knowledge. Ute Eickelkamp (2008) geographically focused on storytelling in the Ernabella on Anangu Pitjantjatjara Yankunytjatjara (APY) Lands in northwest South Australia exploring "place of story in children's life" (p. 87). Ellis et al. (2019) in the Ngaanyatjarra Lands specifically, documenting a guessing game in the sand called that focuses on "the domains of kinship and spatial awareness" (p. 164).

In regard to informal learning, Kral \& Ellis (2008) suggested "literacy is being acquired and transmitted 'out-of-school'" (p. 167). More recently, Davidson (2018) published her doctoral thesis exploring Murrinhpatha 
affiliative and disaffiliative actions in talk with peers in Wadeye, north-western Australia. The study was carried out with eight children from the area. The findings indicated that certain age range uses of categories in talk. Children aged three to six focus on themselves as individuals. There is currently research missing in this area in majority of other First Nations contexts in Australia.

\section{Evidence and Literature Relating to Schooling}

Popular Western epistemologies for Indigenous education programs have continued to dominate early childhood pedagogy and practice in First Nations communities in Australia and are derived from a deficit discourse. This is the "result of deeply paternalistic policy approaches based on evidence based decision-making that are detached from local realities" (Emery \& Habel, 2017, p. 17). Two literature reviews have been conducted on First Nations education in Australia. The first was conducted by McConnochie \& Russell (1982). The review presented the results of a 1981 research project into early childhood services for 'Aboriginal children in Australia'. The report and project were an initiative of the Australian Commonwealth Department of Education and Training and aimed at giving a history of early childhood services and training in Australia, a state by state update of current services and training programs across the nation. The second literature review was carried out by R. J. Schwab (2018) presenting a review of First Nations education literature over the past twenty-five years. In the late-1990s and early-2000s, Schwab also discussed the notion of Community Education Centres (Schwab, 1998; Schwab \& Sutherland, 2001), providing an overview of five case studies from overseas and Australia, in Maningrida far North Arnhem Land.

From the mid-to-late-2000s, policy in First Nations education increased in paternalistic patterns (Altman, 2007). With the occurrence of the Northern Territory Intervention, academics discussed the importance of valuing diversity (Altman, 2009) and the critical discourse that developed during the Closing the Gap speeches and reports (Moore, 2012). In 2004, Townsend-Cross discussed the importance of Indigenous perspectives in early childhood education at a keynote address at the Pacific Early-Childhood Education Research Association conference. During the address, she made note of the importance of 'culturally responsive teaching'. In 2015, Perso \& Haywood (2015) published an education textbook, Teaching Indigenous Students to provide theoretical and practical understanding for practitioners and pre-service teachers working with Indigenous students and their families in urban, rural and remote contexts. 
Within teaching and the institutions of education in remote areas, there has been a continued stream of literature and policy framed in a deficit discourse however, researchers such as Guenther, Bat \& Osborne (2013) and Osborne \& Guenther (2013) offer a new way of thinking about education that building on success and aspiration. This alternative method of assessment success was termed, 'Red Dirt Thinking'. Since the 1990s, two key studies have taken place to explore the 'gap' between educational and health standards in Aboriginal and non-Aboriginal child populations. These were: Western Australian Aboriginal Child-Health Survey (Telethon Kids Institute, n. d.) and Footprints in Time: The Longitudinal Study of Indigenous Children (Australian Government, 2014). However, both studies still objectified children within Western norms and do not value First Nations child rearing practices.

\section{Learning On-Country}

Children's learning experiences both in and out-of-school provide the profound effects on the child's achievement and how they function in society (Hull \& Schultz, 2002; Resnick, 1987). The term 'out-of-school learning' refers to the acquisition of knowledge or skills out of the formalised school environment (Banks et al., 2007; Vadeboncoeur, 2006). Family learning seeks to develop lifelong learning across all age groups formally, informally or in a non-formal manner (UNESCO Institute for Lifelong Learning, 2017). Out-of-school learning can be described as 'going bush' or 'on-country' and is a key practice in the region that connects people to their lands through caring for country, hunting and ceremony (Fielding, Lawson, Lawson \& Vost, 2010). In 2011, Josie Douglas published an article from Central Australia entitled, "Learning from country: the value of country visits in remote schools for community engagement and natural and cultural resource management". The study was conducted with school aged children, during school time from two sites however, this research did not include children aged before transition class, three years of age nor did it include out-of-school time. In 2015, Douglas published her thesis and the fifty participants of the study were from young persons and beyond. Both studies are extremely valuable and relevant when considering the everyday and out-of-school learning that occurs for peoples in Central Australia and this study could be carried in other First Nations contexts in Australia, particularly related to early years learning.

Children's Ground have collaborated with First Nations traditional owners and families across a range of communities in the Northern 
Territory. Children's Ground take a health, education and wellbeing based approach to early childhood education. Learning is on-country and intergenerational with the wider community through three specific theories of change, focusing on community, systems and society change (Children's Ground, 2013). Although the holistic, on-country learning program is currently running in a remote setting and is highly admirable, the generalisability may be difficult to emulate in a larger quantity of remote settings. Due to the program being in its infancy, there is no literature outlining the program limitations, successes or recommendations.

First Nations Early Childhood Educators

Since the 1980s, a range of literature has been presented from the view and importance of First Nations early childhood educators in schools. Nungarrayi-Egan (1983) described the importance of employing First Nations educators at the Yuendumu Aboriginal Cultural Pre-School. In 1999, the Learning Lessons: An Independent Review of Indigenous Education in the Northern Territory was published by the Northern Territory Department of Education and in the recommendations the authors signalled the importance of First Nations educators in the classroom. Fasoli \& Ford (2001) conducted an eighteen-month study of three First Nations early childhood educators in three different locations that aimed to document early childhood practical knowledge of teaching practices that are valuable in the context. Phillips \& Watt (2004) produced an overview of the learning journey of staff and students for Batchelor Institute, formally known as 'Remote Area Teacher Education' from 1999 to 2003. The program began in 1976 in response to the demand for "increased teacher education for Aboriginal teachers in Aboriginal community schools" (Phillips \& Watt, 2004, p. 2). The program started in Yikarrala with ten students and by 1988, one-hundred and fifteen students were enrolled. The training program aimed to provide education training for Aboriginal people in remote areas to provide a pedagogy that supported 'both-ways' teaching and learning popular rhetoric for the time period. The program significantly downsized in the early-2000s due to financial difficulties. More recently two pieces of literature have presented the narratives of First Nations educators themselves. Grace \& Trudgett (2012) presented the challenges to engagement for First Nations families such as racism and strengths-based strategies for First Nations early childhood workers to engage in the early childhood education space. In 2018, We Always Stay (Hall, 2018) was published which presented stories of seven First Nations teachers from remote Central Australia. 


\section{Remote Schooling}

Within the remote context, a range of reviews have occurred since the 1990s. The first is the Tri State Project Review (1990) which outlined three sections: the 'problem' of remote education across the tri state area; detail of current state or territory and; a detail of the objectives. In the case, the tri state area referred to Western Australia, South Australia and Northern Territory. In 1996, the Commonwealth of Australia outlined a report on language learning entitled, Desert Schools (Clayton, Barnett, Kemelfield, \& Mulhauser, 1996). Both reports, failed to provide the perspectives of families or the community and continued to analyse education outcomes based on Western ideologies and epistemologies. Tamisari \& Milmilany (2003) presented a review of education in the Yolnu region and the emergence of a bicultural curriculum initiative. This research could be re-created across all First Nations regions to give a place-based overview and recommendations for future in consultation with families and the community.

\section{Playgroup and Pre-School Programs}

In 2016 Gregory, Harman-Smith, Sincovich, Wilson \& Brinkman conducted a review of the impact of playgroups across Australia. This was carried out by measuring attendance and the impact on child development using the Australia Early Development Census (AEDC) National data. There is a small section in remote and very remote findings however, the data collection methods do not consider the unique context of education in remote Australia. The AEDC data measures Western norms of childhood development. Overall, greater consideration for Moss, Harper \& Silburn (2015) presented literature relating to the transition to a preschool readiness program in Central Australia. Vockins, Armstrong \& Springs (2006) presented an evaluation of the Tjitji Tjutajar Project in the Pitjantjatjara region of Central Australia reviewing the early childhood program, an initiative by Australian Government. To date, research has been based around a Western construct of schooling and has failed to acknowledge First Nations learning processes. Although a range of research has been carried out to document First Nations language learning, it has been rarely used to influence pedagogy.

\section{About the author}

Catherine Holmes recently completed her master's research on the introduction of Montessori teaching and learning practices in an Early Childhood 
classroom in a remote Indigenous school. She now hopes to extend her research to observe and describe the impact of play in child development within a remote Indigenous context. Catherine has a background in Early Childhood education and adult learning with Aboriginal and Islander Education Officers in the Central Australia.

\section{References}

Altman, J. C. (2007). The Howard Government's Northern Territory intervention: Are Neo-paternalism and Indigenous Development Compatible. Canberra: Australian National University, Centre for Aboriginal Economic Policy Research Acton.

Byers, L., Kulitja, S., Lowell, A. \& Kruske, S. (2012). "Hear our stories": Child rearing practices of a remote Australian Aboriginal community. Australian Journal of Rural Health, 20(6), 293-297. doi: 10.1111/j.1440-1584.2012.01317.x

Children's Ground. (2013). Children's Ground in Kakadu West Arnhem Land, Final Evaluation Report 2013-2017. https://www.childrensground.org.au/wp-con tent/uploads/2020/02/Kakadu-West-Arnhem-Final-Evaluation-2013-2017.pdf

Clayton, J., Barnett, J., Kemelfield, G. \& Mulhauser, P. (1996). Desert Schools. An investigation of English language and literacy among young aboriginal people in seven communities. Report to the Commonwealth Department of Employment, Education and Training. Canberra: AGPS.

Coombs, H. C., Brandl, M. M. \& Snowdon, W. E. (1983). A Certain Heritage: Programs for and by Aboriginal Families in Australia (Vol. 9). Canberra: Australian National University Press, Centre for Resource and Environmental Studies.

Davidson, L. (2018). Allies and Adversaries: Categories in Murrinhpatha Speaking Children's Talk (PhD thesis). School of Languages and Linguistics, Canberra.

Disbray, S. (2008). Story-telling Styles: A study of adult-child interactions in Tennant Creek. In J. Simpson \& G. Wigglesworth (Eds.), Children's Language and Multilingualism (pp. 45-65). London, New York: Continuum. 
Dodd, J. \& Jackiewicz, T. (2015). The negotiations of involved fathers and intensive mothers around shared-bed sleeping with infants (co-sleeping). Health Sociology Review, 24(2), 213-225.

Douglas, J. (2011). Learning from Country: The value of country visits in remote schools for community engagement and natural and cultural resource management. Desert Knowledge CRC Report, 69. http://www.nintione.com. au/resource/NintiOneResearchReport_69_Thevalueofcountryvisitsinremote schools.pdf

Douglas, J. (2015). Kin and knowledge: The meaning and acquisition of Indigenous ecological knowledge in the lives of young Aboriginal people in Central Australia (PhD thesis). Charles Darwin University, Alice Springs.

Durack, M. (1977). Tjakamarra-Boy Between Two Worlds. Perth: Literary Board of Aust.

Eickelkamp, U. (2005). The Artifice of Play. Presented at Imagining Childhood Symposium, Alice Springs, NT: Charles Darwin University. http://citeseerx. ist.psu.edu/viewdoc/download?doi=10.1.1.525.2481\&rep=rep1\&type =pdf

Eickelkamp, U. (2008). "I don't talk story like that:" On the social meaning of children's sand stories in Ernabella. In J. Simpson \& G. Wigglesworth (Eds.), Children's Language and Multiculturalism: Indigenous Language Use at Home and School (pp. 78-99). London and New York, NY: Continuum.

Eickelkamp, U. (2010). Children and youth in Aboriginal Australia: An overview of the literature. Anthropological Forum, 20(2), 147-166. doi: 10.1080/ 00664677.2010 .487297

Eickelkamp, U. (2011). Growing Up in Central Australia: New Anthropological Studies of Aboriginal Childhood and Adolescence. Berghahn: New York.

Ellis, E. M., Green, J., Kral, I. \& Reed, L. W. (2019). "Mara yurriku": Western Desert sign languages. Australian Aboriginal Studies, 2, 89-111.

Emery, S. \& Habel, C. (2017). Video games and Indigenous education: Let's bridge the 'epistemology gap'. ergo, 4(1). https://ojs.unisa.edu.au/index.php/ ergo/article/view/1451

Fasoli, L. \& Ford, M. (2001). Indigenous early childhood educators' narratives: Relationships, not activities. Australasian Journal of Early Childhood, 26(3), 18-22. https://doi.org/10.1177/183693910102600305

Fielding, K., Lawson, D., Lawson, J. \& Vost, J. (2010). Maliki nintirringuttja-ku: Strangers Coming in Learning Ngaanyatjarra way. Ngaanyatjarra Lands: Ngaanyatjarra Council and the Shire of Ngaanyatjarraku.

Franks, C. \& Curr, B. (1996). Keeping Company: An Inter-cultural Conversation: Irlkwatherre, Yatyarre, Tantye/rtantye, Ngapartji-ngapartji, Kepenhe, Jankujanku. Australia: Centre for Indigenous Development Education and Research, University of University of Wollongong.

Geia, L. K., Hayes, B. \& Usher, K. (2011). A strengths based approach to Australian Aboriginal childrearing practices is the answer to better outcomes in Aboriginal family and child health. Collegian, 18(3), 99-100. doi: 10.1016/j. colegn.2011.05.002.

Grace, R. \& Trudgett, M. (2012). It's not rocket science: The perspectives of Indigenous early childhood workers on supporting the engagement of Indigenous families in early childhood settings. Australasian Journal of Early Childhood, 37(2), 10-18. https://doi.org/10.1177/183693911203700203 
Gray, A., Trompf, P. \& Houston, S. (1991). The decline and rise of Aboriginal families. In J. Reid \& Peggy Trompf (Eds.), The Health of Aboriginal Australia (pp. 80-122). Marrickville NSW: Harcourt Brace Jovanovich.

Gregory, T., Harman-Smith, Y., Sincovich, A., Wilson, A. \& Brinkman, S. (2016). It takes a village to raise a child: The influence and impact of playgroups across Australia. Adelaide: Telethon Kids Institute.

Guenther, J., Bat, M. \& Osborne, S. (2013). Red dirt thinking on educational disadvantage. Australian Journal of Indigenous Education, 42(2), 100. doi: 10.1017/jie.2013.18

Gutiérrez, K. D. \& Rogoff, B. (2003). Cultural ways of learning: Individual traits or repertoires of practice. Educational Researcher, 32(5), 19-25.

Haagen, C. (1994). Bush Toys: Aboriginal Children at Play. Canberra: Aboriginal Studies.

Hall, L. (Comp.). (2018). We Always Stay: Stories from seven remarkable Aboriginal teachers in remote Australia. Batchelor, NT: Batchelor Institute Press

Hamilton, A. (1981). Nature and Nurture: Aboriginal Child-Rearing in North-Central Arnhem Land. Canberra: Australian Institute of Aboriginal Studies.

Hancock, H. (2006). Aboriginal Women's Perinatal Needs, Experiences, and Maternity Services: A Literature Review to Enable Considerations to be Made about Quality Indicators. Alice Springs: Ngaanyatjarra Health Service.

Haviland, J. B. (1998). Guugu Yimithirr cardinal directions. Ethos, 26(1), 25-47.

Heath, S. B. (1983). Ways with Words: Language, Life and Work in Communities and Classrooms. Cambridge: Cambridge University Press.

Heath, S. B. (1989). Oral and literate traditions among Black Americans living in poverty. American Psychologist, 44(2), 367-373. https://doi.org/10.1037/00 03-066X.44.2.367

Heath, S. B. \& Street, B. V. (2008). On Ethnography: Approaches to Language and Literacy Research. Language \& Literacy (NCRLL). Columbia, NY: ERIC.

Hilliard, W. M. (1968). The People in Between: The Pitjantjatjara People of Ernabella. London: Hodder \& Stoughton.

Hull, G. A. \& Schultz, K. (2002). School's out: Bridging out-of-School Literacies with Classroom Practice. Columbia University, NY: Teachers College Press.

Isaacs, J. (1992). Australian Dreaming: 40000 Years of Aboriginal History. Sydney: New Holland Publishing Australia Pty Ltd.

Jacobs, A. M. (1988). A descriptive study of the bilingual language development of Aboriginal children in the Eastern Goldfields of Western Australia. Australian Journal of Human Communication Disorders, 16(2), 3-16. https://doi. org/10.3109/asl2.1988.16.issue-2.01

Jewell, T. (2008). Martu tjitji pakani: Martu Child Rearing and its Implications for the Child Welfare System (doctoral thesis). University of Western Australia, Perth, Australia.

Kaberry, P. ([1939] 2003). Aboriginal Woman Sacred and Profane. Melbourne: Routledge.

Kral, I. (2007). Writing Words-Right Way!: Literacy and Social Practice in The Ngaanyatjarra World (thesis). Australian National University, Australia. https://openresearch-repository.anu.edu.au/handle/1885/9216

Kral, I. \& Ellis, E. M. (2008). Children, language and literacy in the Ngaanyatjarra Lands. In. G. Wigglesworth \& J. Simpson (Eds.), Children's Language and 
Multilingualism: Indigenous Language Use at Home and School. London: Continuum.

Kruske, S., Belton, S., Wardaguga, M. \& Narjic, C. (2012). Growing up our way: The first year of life in remote Aboriginal Australia. Qualitative Health Research, 22(6), 777-787. doi: 10.1177/1049732311432717

Langlois, A. (2004). Alive and Kicking: Areyonga Teenage Pitjantjatjara. Canberra: Pacific Linguistics. https://openresearch-repository.anu.edu.au/bit stream/1885/146181/1/PL-561.pdf

Laughren, M. (1978). Directional Terminology in Warlpiri (Vol. 8). Launceston: Tasmanian College of Advanced Education.

LeVine, R. A. \& New, R. S. (Eds.). (2008). Anthropology and Child Development: A Cross-Cultural Reader. New Jersey: Wiley-Blackwell.

Lohoar, S., Butera, N. \& Kennedy, E. (2014). Strengths of Australian Aboriginal Cultural Practices in Family Life and Child Rearing. Canberra: Australian Institute of Family Studies.

Malinowski, B. (1913). The Family Among the Australian Aborigines. New York: Schocken Books.

Malinowski, B. (1927). The Father in Primitive Psychology. New York: Norton.

Martin, K. (2008). Please Knock Before you Enter: Aboriginal Regulation of Outsiders and the Implications for Researchers. Teneriffe, Queensland: Post Pressed.

Martin, K. \& Mirraboopa, B. (2003). Ways of knowing, being and doing: A theoretical framework and methods for indigenous and indigenist re-search. Journal of Australian Studies, 27(76), 203-214. https://doi.org/10.1080/1444 3050309387838

McConnochie, K. R. \& Russell, A. (1982). Early Childhood Services for Aboriginal Children. GPO Box 84, Canberra, ACT 2601 Australia.: Australian Government Publishing Service (AGPS).

McCoy, B. (2009). 'Living between two worlds': Who is living in whose worlds? Australasian Psychiatry, 17(sup1), S20-S23.

Merlan, F. (1997). Fighting over country: Anthropological perspectives. In D. E. Smith \& J. Finlayson (Eds.), Fighting over Country: Anthropological Perspective. Canberra, ACT: Centre for Aboriginal Economic Policy Research, Research School of Social Sciences, College of Arts \& Social Sciences, The Australian National University.

Miller, P. (1982). Amy, Wendy, and Beth: Language Learning in South Baltimore. Austin: University of Texas Press.

Moore, R. (2012). Whitewashing the Gap. International Journal of Critical Indigenous Studies, 5(2), 2-12. https://doi.org/10.5204/ijcis.v5i2.86

Morphy, F. (2006). Lost in translation?: Remote Indigenous households and definitions of the family. Family Matters, 73, 23-31. https://aifs.gov.au/sites/ default/files/fm\%281\%29.pdf

Morton, J. (1989). Mama, papa, and the space between: Children, sacred objects, and transitional phenomena in aboriginal Central Australia. In L. B. Boyer \& S. A. Grolnick (Eds.), The Psychoanalytic Study of Society: Essays in Honour of Paul Parin (pp. 191-225). Hillsdale, NJ, and London: The Analytic Press. 
Moss, B., Harper, H. \& Silburn, S. (2015). Strengthening Aboriginal child development in central Australia through a universal preschool readiness program. Australasian Journal of Early Childhood, 40(4), 13-20.

Mountford, C. P. (1973). A mountain devil myth and ceremony for boys \& a leaf game for girls. In E. S. Phillips (Ed.), The Australian Aboriginal Heritage: An Introduction through the Arts (pp. 59-64). Sydney: IPC Books Pty Ltd.

Musharbash, Y. (2013). Night, sight, and feeling safe: An exploration of aspects of Warlpiri and Western sleep. The Australian Journal of Anthropology, 24(1), 48-63. https://doi.org/10.1111/taja.12021

Myers, F. R. (1991). Pintupi Country, Pintupi Self: Sentiment, Place, and Politics among Western Desert Aborigines. California: University of California Press.

Nakata, M., Nakata, V., Keech, S. \& Bolt, R. (2012). Decolonial goals and pedagogies for Indigenous studies. Decolonization: Indigeneity, Education \& Society, 1(1), 120-140. https://www.researchgate.net/publication/267202834_ Decolonial_Goals_and_Pedagogies_for_Indigenous_Studies

Nungarrayi-Egan, J. (1983). The Yuendumu Aboroginal Cultural Pre-School. In F. Gale (Ed.), We Are Bosses Ourselves: The Status and Role of Aboriginal Women Today (pp. 122-123). Canberra: Humanities Press International.

Ochs, E. (1988). Culture and Language Development: Language Acquisition and Language Socialization in a Samoan village. Cambridge: Cambridge University Press.

Osborne, S. \& Guenther, J. (2013). Red dirt thinking on aspiration and success. Australian Journal of Indigenous Education, 42(2), 88-99. doi: 10.1017/ jie.2013.17

O'Shannessy, C. (2005). Light Warlpiri: A new language. Australian Journal of Linguistics, 25(1), 31-57. https://doi-org.virtual.anu.edu.au/10.1080/0726 8600500110472

O'Shannessy, C. (2011). Young children's social meaning making in a new mixed language. In U. Eickelkamp (Ed.), Growing Up in Central Australia: New Anthropological Studies of Aboriginal Childhood and Adolescence. Berghahn: New York.

Phillips, J. \& Watt, R. (2004). Strong Learners: The Learning Journey of Students and Staff in the Certificate III in Indigenous Education Work at Batchelor Institute 1999-2003. Darwin: Batchelor.

Piaget, J. \& Cook, M. (1952). The Origins of Intelligence in Children (Vol. 8). New York: International Universities Press New York.

Perso, T. \& Hayward, C. (2015). Teaching Indigenous Students: Cultural Awareness and Classroom Strategies for Improving Learning Outcomes. Crows Nest, NSW: Allen \& Unwin.

Pollard, C. M., Nyaradi, A., Lester, M. \& Sauer, K. (2014). Understanding food security issues in remote Western Australian Indigenous communities. Health Promotion Journal of Australia, 25(2), 83-89. doi: 10.1071/HE14044

Priest, K., King, S., Brown, W. N., Nangala, I. \& Nangala, M. (2007). Warrki Jarrinjaku Jintangkamanu Purananjaku "Working Together Everyone and Listening": Aboriginal Child Rearing in Remote Central Australia. Canadian Journal of Native Education, 30(1), 61-74. 
Resnick, L. B. (1987). The 1987 presidential address learning in school and out. Educational Researcher, 16(9), 13-54.

Robinson, G. (1990). Separation, retaliation and suicide: Mourning and the conflicts of young Tiwi men. Oceania, 60(3), 161-178.

Robinson, G. W. (1992). Dependence and Conflict: Adolescence and Family in an Aboriginal Community of North Australia. Sydney: University of New South Wales.

Rockchild, L. (1999). Bush Toys: A Living History. Alice Springs: Liesl Rockchild Arts Management and Design.

Rogoff, B. (1990). Apprenticeship in thinking: Cognitive development in social context: New York: Oxford University Press.

Rogoff, B. (1998). Cognition as a collaborative process. In W. Damon, D. Kuhn \& R. S. Siegler (Eds.), Cognition, Percention and Language: Handbook of Child Psychology (5 ed., Vol. 2). New York: Wiley.

Rogoff, B. \& Chavajay, P. (1995). What's become of research on the cultural basis of cognitive development? American Psychologist, 50(10), 859.

Rogoff, B., Mistry, J., Göncü, A. \& Mosier, C. (1993). Guided participation in cultural activity by toddlers and caregivers. Monographs of the Society for Research in Child Development, 58(8), v-vi, 1-174; discussion 175-9.

Roheim, G. (1974). The Children of the Desert: The Western Tribes of Central Australia (Vol. 1). New York: Basic Books.

Roheim, G. (1988). Children of the Desert II: Myths and Dreams of the Aborigines of Central Australia (Vol. 2). Melbourne: Oceania Publications, University of Sydney.

Ryan, F. (2011). Kanyininpa (Holding): A way of nurturing children in Aboriginal Australia. Australian Social Work, 64(2), 183-197. https://doi.org/10.1080/ 0312407X.2011.581300

Shaw, G. (2002). An Ethnographic Exploration of the Development of the Child Rearing Style among the Ngaanyatjarra People from the Pre-Contact Era to the Present (masters thesis). University of New South Wales, Sidney, Australia.

Schwab, R. (1998). Educational 'failure' and educational 'success' in an Aboriginal community. Canberra, ACT: The Australian National University.

Schwab, R. J. (2018). Why Only One in Three? The Complex Reasons for Low Indigenous School Retention: Canberra, ACT: Centre for Aboriginal Economic Policy Research, Research School of Social Sciences, College of Arts \& Social Sciences, The Australian National University.

Schwab, R. G. \& Sutherland, D. (2001). Building Indigenous Learning Communities. https://core.ac.uk/download/pdf/156615678.pdf

Simpson, J. \& G. Wigglesworth (2008). Children's language and multilingualism: Indigenous language use at home and school. London: Continuum.

Tamisari, F. \& Milmilany, E. (2003). Dhinthun Wayawu-looking for a pathway to knowledge: Towards a vision of Yolngu education in Milingimbi. The Australian Journal of Indigenous Education, 32, 1-10. doi: https://doi.org/10.1017/ S132601110000377X

Telethon Kids Institute (n. d.). WA Aboriginal Child Health Survey (WAACHS). https://www.telethonkids.org.au/our-research/aboriginal-health/waachs/ 
Thomson, D. F. (1936). Fatherhood in the Wik Monkan tribe. American Anthropologist, 38(3), 374-393.

Thomson, D. F. (1946). Names and naming in the Wik Monkan tribe. The Journal of the Royal Anthropological Institute of Great Britain and Ireland, 76(2), 157-168.

Thomson, D. F. (1975). Bindibu Country. Melbourne: Thomas Nelson.

Thomson, D. F. (1983). Children of the Wilderness. South Yarra, Victoria: Currey O’Neil Ross.

Tonkinson, R. (2013). Dream-spirits and innovation in aboriginal Australia's western desert. International Journal of Transpersonal Studies, 32(1). doi: 10.24972/ijts.2013.32.1.127

Townsend-Cross, M. (2004). Indigenous Australian perspectives in early childhood education [Taken from a keynote address at the Pacific Early-Childhood Education Research Association. International Conference (5th: 2004: Melbourne)]. Australian Journal of Early Childhood, 29(4), 1-6. https://doi. org/10.1177/183693910402900402

Tri-State Project. (1990). Tri-State Project Draft Report: Improving Aboriginal Student Learning Outcomes through Co-Operative Education Services. Perth: Unpublished manuscript.

UNESCO Institute for Lifelong Learning. (2017). Engaging Families in Literacy and Learning. UNESCO Institute for Lifelong Learning. https://unesdoc.unesco. org/ark:/48223/pf0000249463

Vadeboncoeur, J. A. (2006). Chapter 7: Engaging young people: Learning in informal contexts. Review of Research in Education, 30(1), 239-278. https:// doi.org/10.3102/0091732X030001239

Vockins, C., Armstrong, C. \& Springs, N. T. (2006). Tjitji-Tjutatjara Kunpu Kulintjaku (Listening up Strong for Little Kids) Innovative Evaluation in Remote Indigenous Communities. Paper presented at the AES International Conference. Darwin, Australasian Evaluation Society.

Vygotsky, L. S. (1967). Play and its role in the mental development of the child. Soviet psychology, 5(3), 6-18.

Wallace, P. \& Wallace, N. (1968). Children of the Desert. Sydney: Nelson.

Waltja Tjutangku Palyapayi Association. (2001). Pipirri wiimaku 'for the little kids': Innovative Child Care Report 2000-2001. Alice Springs, NT: Waltja Tjutangku Palyapayi Aboriginal Association.

Wheatley, N. (2017). Playground: Listening to Stories from Country and from Inside the Heart. Crows Nest, NSW: Allen \& Unwin.

Wilkins, D. (2006). Towards an Arrernte grammar of space. In S. C. Levinson \& D. Wilkins (Eds.), Grammars of Space: Explorations in Cognitive Diversity (pp. 24-62). Cambridge: Cambridge University Press.

Woenne, S. T. (1973). Children's games. In E. S. Phillips (Ed.), The Australian Aboriginal Heritage: An Introduction through the Arts. Sydney, NSW: IPC Books Pty Ltd. 